\title{
PENDUGAAN DEFISIT DAN SURPLUS AIR UNTUK PENGEMBANGAN TANAMAN JAGUNG (ZEA MAYS L.) DI KABUPATEN GORONTALO DENGAN MENGGUNAKAN MODEL SIMULASI NERACA AIR
}

\section{Prediction of Water Deficit and Surplus for the Development of Maize (Zea Mays L.) in the District Gorontalo Using Water Balance Simulation Model}

\author{
Yunnita Rahim \\ Johannes E. X. Rogi \\ Samuel D. Runtunuwu
}

\begin{abstract}
This study aims to apply the water balance simulation model developed by Handoko (1992) for estimating the deficit and surp4lus water for the development of corn plants in the province of Gorontalo. This study was implemented from April to August 2014 in the District of Gorontalo. The study metods included field studies and modeling of water balance using a simulation model by Handoko (1992). The results showed that the period of water deficit was found in August and September where rainfall $(C h)$ is smaller than potential evapotranspiration (ETP) whereas periods of surplus water in the district of Gorontalo found in January to July and October to December where rainfall (Ch) exceeds potential evepotranspiration (ETP).
\end{abstract}

Keywords: Corn, Deficit and Surplus Water, District of Gorontalo, Water Balance Simulation Model

\begin{abstract}
ABSTRAK
Penelitian ini bertujuan untuk menerapkan model simulasi neraca air yang dikembangkan oleh Handoko (1992) untuk menduga defisit dan surplus air untuk pengembangan tanaman Jagung di Provinsi Gorontalo. Penelitian ini di laksanakan mulai bulan April s/d Agustus 2014. di Kabupaten Gorontalo. Metode Penelitian ini meliputi penelitian lapangan dan pemodelan neraca air dengan menggunakan model simulasi yang dikembangkan oleh Handoko 1992. Hasil penelitian menunjukkan bahwa periode Defisit air ditemukan pada bulan Agustus dan bulan september dimana Curah hujan $(\mathrm{Ch})$ lebih kecil dari Evapotranspirasi Potensial (ETP) sedangkan periode Surplus air di kabupaten Gorontalo ditemukan pada bulan Januari sampai Juli dan pada bulan Oktober sampai Desember dimana Curah hujan (Ch) melebihi Evapotranspirasi Potensial (ETP)
\end{abstract}

Kata Kunci : Defisit dan Surplus Air, Jagung, Kabupaten Gorontalo, Model Simulasi Neraca Air 


\section{PENDAHULUAN}

Pengembangan tanaman semusim seperti Jagung di Provinsi Gorontalo dirasakan sudah cukup mendesak, sejalan dengan meningkatnya konsumsi bahan makanan dan kebutuhan industri dengan bahan baku dasar Jagung. Jagung merupakan sumber karbohidrat yang dapat berfungsi sebagai pengganti bahan makanan pokok seperti beras.

Produksi Jagung di Provinsi Gorontalo Tahun 2007 hingga 2013 tertinggi pada Tahun 2008 sebesar 753.598 ton dan mengalami penurunan Tahun 2009 sebesar 569.110 ton (Badan Pusat Statistik,2013). Hal ini disebabkan oleh banyak faktor diantaranya kondisi iklim yang kurang menguntungkan, ditandai dengan periode penghujan singkat dan musim kemarau yang lama sehingga mengakibatkan pengelolaan tanaman di lahan kering terkendala oleh ketersediaan air yang hanya bersumber dari curah hujan.

Fenomena El Nino terjadi pada Tahun 2009 berupa kemarau panjang yang terjadi secara ekstrim yang mengakibatkan lahan yang ditanami Jagung mengalami puso/kerusakan, sesuai data puso yang terjadi sebesar $15.700 \mathrm{Ha}$ (Dinas Pertanian Dan Ketahanan Pangan Provinsi Gorontalo, 2011).

Kondisi air dalam tanah sangat mempengaruhi pertumbuhan tanaman secara langsung. Pada budidaya tanaman lahan kering, air merupakan faktor pembatas yang paling menentukan. Sumber air utama bagi pertumbuhan tanaman adalah hujan. Bervariasinya hujan, baik dalam jumlah, intensitas, dan waktu datangnya hujan merupakan penyebab sulitnya memprediksi waktu tanam atau mengatur pola tanam yang diakibatkan oleh ketersediaan air yang bersifat fluktuatif.

Jumlah air di suatu luasan tertentu di permukaan bumi dipengaruhi oleh besarnya air yang masuk ( input) dan keluar (output) pada jangka waktu tertentu. Karena air bersifat dinamis maka nilai neraca air selalu berubah dari waktu ke waktu sehingga di suatu tempat kemungkinan bisa terjadi kelebihan air (surplus) ataupun kekurangan (defisit). Apabila kelebihan dan kekurangan air ini dalam keadaan ekstrim tentu dapat menimbulkan bencana, seperti banjir ataupun kekeringan. Bencana tersebut dapat dicegah atau ditanggulangi bila dilakukan pengelolaan yang baik terhadap lahan dan lingkungannya.

Keunggulan teknologi pemodelan neraca air adalah dapat dimanfaatkan untuk memprediksi surplus dan defisit air di suatu wilayah (Djufry, 2012) dan merupakan salah satu metode yang sering digunakan untuk menduga dinamika kadar air tanah selama periode pertumbuhan tanaman, sehingga dapat dihitung jumlah kebutuhan air tanaman untuk dapat berproduksi, terutama pada periode kritis yaitu pada saat kadar air tanah sangat rendah maupun dalam keadaan normal.

Penelitian ini bertujuan dalam menerapkan model simulasi neraca air yang dikembangkan oleh Handoko (1992) untuk menduga defisit dan surplus air untuk pengembangan tanaman Jagung di Kabupaten Gorontalo Provinsi Gorontalo.

\section{BAHAN DAN METODE}

Penelitian ini di laksanakan selama 4 bulan mulai bulan April s/d Agustus 2014. Penelitian ini di laksanakan dalam bentuk percobaan lapang di Kelurahan Tenilo Kabupaten Gorontalo Provinsi Gorontalo. Uji tanah di Laboratorium Terpadu dan untuk memvalidasi model di Laboratorium Modeling Tanaman Fakultas Pertanian Unsrat. Bahan yang digunakan dalam penelitian ini adalah benih jagung varietas hibrida Bisi 18, pupuk urea, SP-36, Phonska, data sekunder berupa data iklim Kabupaten Gorontalo selama 10 tahun meliputi curah hujan, kelembaban udara, kecepatan angin, radiasi matahari dan suhu. Dan data penunjang lainnya berupa peta administrasi, peta jenis tanah. Alat yang digunakan adalah Global Posisioning System (GPS) untuk menentukan letak Lintang dan Bujur lokasi, bor tanah untuk pengambilan contoh tanah, Ring Sample, Oven, Timbangan digital, computer (hardware), dan alat tulis menulis.

\section{Metode Penelitian}

Penelitian ini meliputi penelitian lapangan dan pemodelan tanaman Jagung dengan menggunakan model simulasi neraca air yang dikembangkan oleh Handoko (1992). 


\section{Prosedur Penelitian}

\section{Prosedur lapang}

Persiapan lahan sebagai media tumbuh, waktu tanam yaitu pada tanggal 14 April 2014 . Benih ditanam menggunakan tugal sikitar $3 \mathrm{~cm}$. Tiap lubang tanam berisi 2 benih, jarak tanam lubang 80 x $40 \mathrm{~cm}$.Pengairan di lakukan sebanyak 6 kali pengairan selama pertumbuhan.Pemupukan di berikan sebanyak dua kali yaitu pada saat tanam dan pada saat tanaman berumur 30 hari. Pemupukan dasar dilakukan dengan dosis pupuk urea $65 \mathrm{~kg} \mathrm{ha}^{-1}$ dan pupuk SP-36 dengan dosis $150 \mathrm{~kg} \mathrm{ha}^{-1}$ diberikan saat tanam diantara lubang tanam dalam barisan. Pemupukan susulan dengan dosis pupuk Phonska dengan dosis $135 \mathrm{~kg} \mathrm{ha}^{-1}$ dan pupuk Urea dengan dosis $200 \mathrm{~kg} \mathrm{ha}^{-1}$ Panen di laksanakan saat tampilan rambut pada tongkol telah mengering.

\section{Pengumpulan Data}

Pengumpulan data sekunder berupa data iklim Kabupaten Gorontalo selama 10 tahun meliputi curah hujan, kelembaban udara, kecepatan angin, radiasi matahari dan suhu. Variable yang diamati di laboratorium adalah sifat fisik tanah yang meliputi tekstur tanah, kadar air, kapasitas lapang $\left(\phi_{\mathrm{fw}}\right)$, titik layu permanen $\left(\phi_{\mathrm{wp}}\right)$, dan berat jenis tanah (bulk density). Untuk pengamatan di lapangan meliputi pengukuran indeks luas daun, tinggi tanaman, dan produksi tanaman.

\section{Analisis Data}

Pengujian secara statistik menggunakan uji-t berpasangan untuk melihat hasil simulasi (run model) dengan hasil pengamatan dilapangan. selain itu pengujian model juga dilakukan dengan metode grafis.

\section{HASIL DAN PEMBAHASAN}

\section{A. Gambaran Umum Kondisi Cuaca di Lokasi}

Penelitian

Berdasarkan data pengamatan unsur iklim yang tercatat di BMKG (Badan Meteorologi
Klimatologi dan Geofisika) Provinsi Gorontalo, mewakili daerah Kabupaten Gorontalo di lokasi penelitian yaitu Desa Tenilo Kabupaten Gorontalo selama periode 10 (sepuluh) tahun mulai tahun 2004 sampai tahun 2013 dengan Latitude $00{ }^{0} 37$ ' LU dan 122.57 BT dan Elevasi Stasiun $17 \mathrm{M}$, menunjukkan bahwa curah hujan rerata bulanan berkisar 137,6 mm. Kecepatan angin bervariasi antara $1-6 \mathrm{~mm} \mathrm{detik}{ }^{-1}$, kelembaban udara relatif berkisar $81 \%$ sepanjang tahun. Radiasi matahari bulanan dengan kisaran tertinggi bulanan $26,45 \quad \mathrm{MJ}^{-1} \mathrm{~m}^{-2}$-hari ${ }^{-1}$ dan terendah $10,62 \mathrm{MJ}^{-1} \mathrm{~m}^{-2}$-hari ${ }^{-1}$.

Rata-rata suhu udara harian di lokasi penelitian adalah $26,7{ }^{\circ} \mathrm{C}$, dengan suhu terendah $23,9^{0} \mathrm{C}$ dan tertinggi $31,8^{0} \mathrm{C}$. Kisaran suhu ini sangat sesuai bagi pertumbuhan tanaman Jagung. Suhu yang dikehendaki tanaman Jagung untuk pertumbuhan optimal antara $27^{0} \mathrm{C}-32^{\circ} \mathrm{C}$. Sedangkan pada proses perkecambahan benih, Jagung memerlukan suhu sekitar $30^{\circ} \mathrm{C}$ (Purwono dan Hartono, 2005).

Sesuai dengan data iklim di wilayah Kabupaten Gorontalo Provinsi Gorontalo, maka dapat disimpulkan bahwa daerah ini cocok untuk pertumbuhan dan perkembangan tanaman Jagung.

\section{B. Pengujian Model}

Model neraca air untuk tanaman jagung yang akan diterapkan di wilayah administrasi Provinsi Gorontalo diadakan pengujian terlebih dahulu. Pengujian model merupakan suatu tahap yang penting untuk mendapatkan kepekaan dari suatu model simulasi terhadap data-data penelitian lapang, agar diperoleh hasil prediksi suatu model yang sesuai atau sebanding dengan nilai observasi lapangan. Banyak terdapat metode statistik yang dapat digunakan untuk membandingkan rata-rata perlakuan, tetapi pada kenyataannya setiap metode mempunyai keterbatasan, sehingga belum ada suatu metode statistik yang cocok untuk pengujian model tanaman yang diterima secara umum. Ini dapat dijadikan suatu alasan mengapa pengujian menjadi penting, untuk mencapai hasil yang diharapkan pengujian dapat dilakukan pada beberapa keadaan yang berbeda (Rogi, 1996).

Berdasarkan data cuaca rata-rata selama periode 10 (sepuluh) tahun terakhir yang diuji meliputi Curah Hujan, Hari Hujan, dan radiasi 
matahari yang bersumber dari BMKG Provinsi Gorontalo, dapat dilihat pada Tabel 1 dan Gambar 1.

Tabel 1. Data Cuaca hasil Run Model dan data lapangan

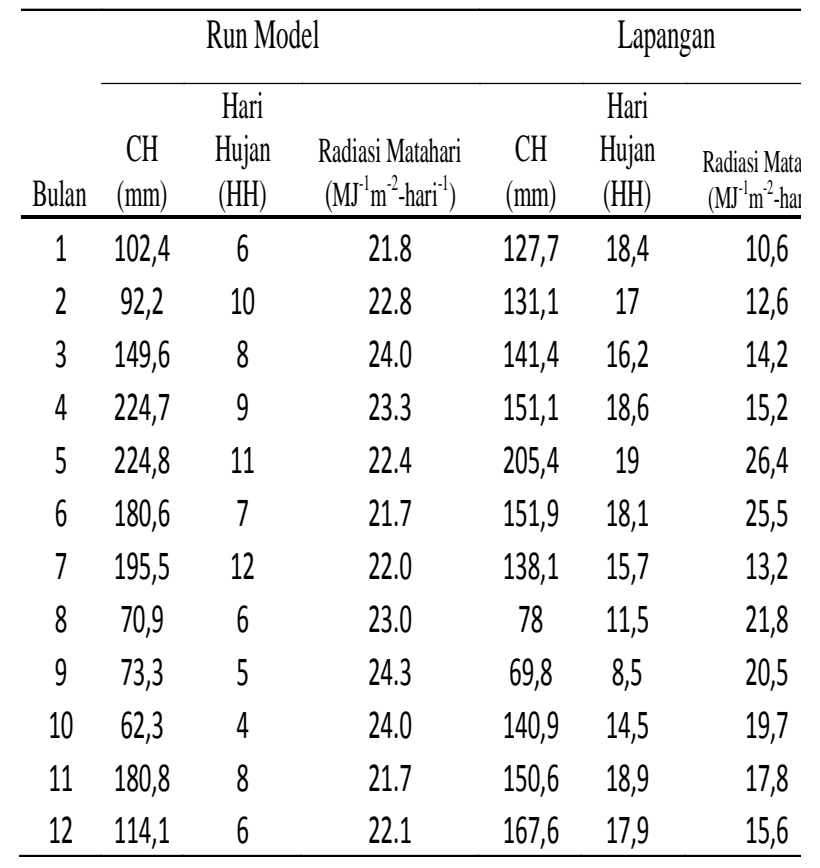

Gambar 1 : Grafik data cuaca hasil Run Model dan data lapangan

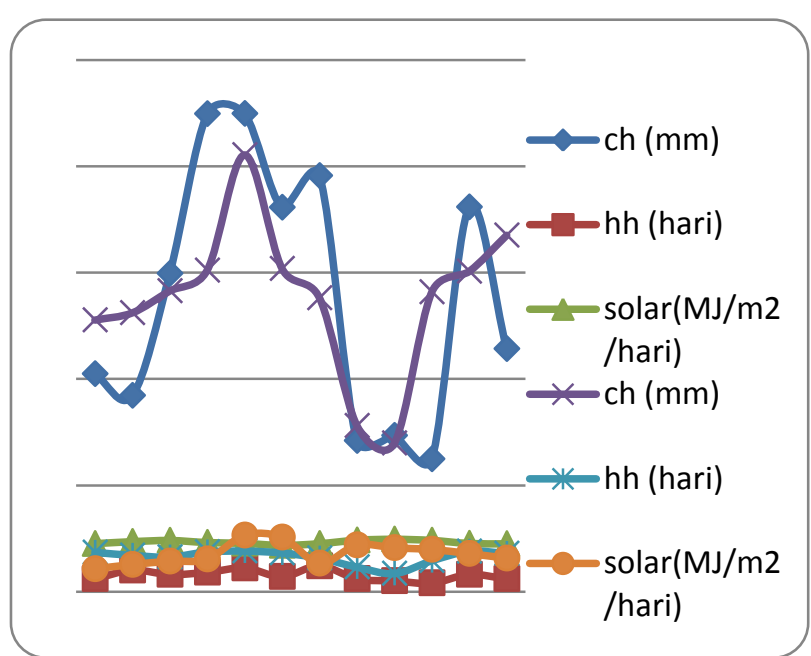

Hasil pengujian dengan uji statistik (uji-t berpasangan) yaitu $\mathrm{P}=0,78$ dan ini mendapatkan hasil yang tidak berbeda nyata $(P>0,05)$, artinya bahwa model mampu menduga pengukuran lapang untuk unsur-unsur cuaca yakni curah hujan hari hujan, sedangkan untuk unsur radiasi matahari terdapat hasil yang berbeda nyata
$(\mathrm{P}<0,05)$, hal ini disebabkan data pengamatan radiasi matahari pada bulan Januari mendapat nilai yang sangat rendah yaitu $10,6\left(\mathrm{MJ}^{-1} \mathrm{~m}^{-2}\right.$-hari ${ }^{-}$ $\left.{ }^{1}\right)$.

\section{Defisit dan surplus Air}

Periode surplus dan defisit air suatu daerah penting diketahui untuk mengatur pola tanam maupun jadwal pemberian air irigasi, sehingga dengan pengelolaan berdasarkan acuan hasil perhitungan neraca air diharapkan akan dapat diperoleh hasil pertanian yang lebih baik. Pemanfaatan prakiraan iklim atau cuaca dalam menentukan waktu tanam serta pola tanam dapat dilakukan dengan mengenal pola curah hujan dan neraca air suatu wilayah. Curah hujan dan evapotranspirasi dapat memberikan keterangan penting tentang perkiraan jumlah air yang dapat diperoleh untuk menentukan periode surplus atau defisit air di lahan, yang dapat dianalisis melalui perhitungan neraca air. Data run model untuk Curah hujan dan Evapotranspirasi Potensial dapat dilihat pada Table 2 dan Gambar 2.

Berdasarkan data tersebut terdapat hubungan nilai antara Curah hujan dengan Evapotranspirasi Potensial. Hasil analisis memberikan gambaran ketersediaan air. Apabila curah hujan melebihi Evapotranspirasi Potensial $(\mathrm{CH}>\mathrm{ETP})$ maka akan terjadi peningkatan air tanah sehingga air tanah cukup tersedia atau surplus dan apabila curah hujan lebih kecil dari evapotranspirasi $(\mathrm{CH}<\mathrm{ETP})$ maka akan berkurang kandungan air dalam tanah atau terjadi defisit pada lahan

Tabel 2. Data run model Curah hujan (ch) dan Evapotranspirasi Potensial (ETP)

\begin{tabular}{lrr} 
Bulan & ch $(\mathrm{mm})$ & \multicolumn{1}{c}{ ETP $(\mathrm{mm})$} \\
\hline Jan & 127,7 & 124,7 \\
Feb & 131,1 & 116,4 \\
Mar & 141,4 & 130,5 \\
A pr & 151,1 & 120,5 \\
Mei & 205,4 & 121,7 \\
Jun & 151,9 & 112,7 \\
Ju1 & 138,1 & 120,8 \\
Aug & 78 & 129,8 \\
Sep & 69,8 & 128,7 \\
Okt & 140,9 & 131,5 \\
Nov & 150,6 & 120,9 \\
Des & 167,6 & 124,5 \\
\hline
\end{tabular}


Gambar 3 : Grafik Data run model Curah hujan (ch) dan Evapotranspirasi Potensial (ETP)

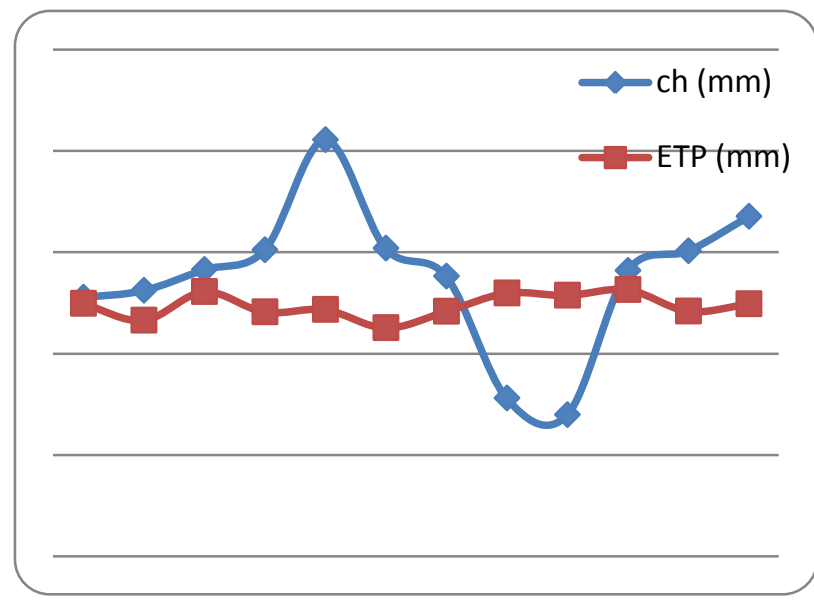

Hasil run model dapat dilihat bahwa kabupaten Gorontalo memiliki periode surplus air yang panjang yakni terjadi pada bulan Januari sampai Juli dan pada bulan Oktober sampai Desember dimana Curah hujan melebihi Evapotranspirasi Potensial sedangkan periode defisit air terjadi pada bulan Agustus dan bulan September dimana Curah hujan lebih kecil dari Evapotranspirasi Potensial. Curah hujan bulanan berkisar antara 69,8 mm (September) sampai dengan 205,4 mm (Mei). Berdasarkan keadaan tersebut tipe zona agroklimat di kabupaten Gorontalo menurut Oldeman adalah tipe iklim B yang menunjukkan bahwa wilayah tersebut memiliki 7- 9 bulan basah berturut-turut dan 2 bulan kering (Kartasapoetra, 1993). Kebutuhan air untuk tanaman palawija adalah $70 \mathrm{~mm} /$ bulan, dengan asumsi bahwa peluang terjadinya hujan adalah $75 \%$ diperlukan curah hujan sebesar 120 $\mathrm{mm} / \mathrm{bulan}$. Lamanya periode pertumbuhan jagung 85 hari, sehingga periode 7-9 bulan basah berurutan dalam satu tahun dipandang optimal untuk tiga kali masa tanam. Makin banyak bulan basah, makin tinggi intensitas tanam daerah tersebut.

Curah hujan yang optimal untuk pertumbuhan Jagung adalah $500-1200 \mathrm{~mm}$, atau $100-295 \mathrm{~mm}$ pada bulan I, $150-310 \mathrm{~mm}$ pada bulan II dan III, serta $100-285 \mathrm{~mm}$ pada bulan IV. Distribusi curah hujan yang merata selama periode pertumbuhan tanaman Jagung akan memberikan hasil baik, yaitu kurang lebih 200 mm setiap bulan, dan suplai air harus cukup terutama pada fase pembungaan hingga pengisian biji.

\section{Sifat Fisik Tanah}

Hasil analisis laboratorium dengan menggunakan contoh tanah tanah diambil dari tiga titik berbeda di lokasi penelitian pada kedalaman $0-50 \mathrm{~cm}$, didapat nilai fraksi pasir $29,62 \%$, debu $35,94 \%$, liat $34,44 \%$. Berdasarkan penggolongan pada segitiga tekstur tanah, komposisi tanah ini termasuk ke dalam tekstur lempung berdebu. Kelas tekstur ini mempunyai kapasitas tampung air maksimum diikuti oleh tanah liat dan paling kecil adalah pasir ( Asdak, 2002).

Sementara untuk hasil kapasitas lapang ( Field Capacty, $F C$ ) rata-rata $32,10 \%$ dan Titik Layu Permanen ( Permanen Wilting Point,PWP ) sebesar $12,31 \%$, sehingga air yang tersedia adalah 19,09\%. Selanjutnya Asdak (2002) mengatakan bahwa nilai kapasitas lapang ( FC ) diartikan sebagai keadaan kelembaban tanah 2 atau 3 hari setelah hujan turun. Nilai FC tergantung pada tekstur tanah. Kelembaban tanah juga sering kali diartikan sebagai air yang tertahan (air tersedia) antara FC dan PWP, dengan demikian merupakan indeks kelembaban tanah yang diperlukan untuk pertumbuhan tanaman.

Berdasarkan hasil pengukuran kadar air tanah di lapangan yang diambil pada tiga titik berbeda pada kedalaman $0-50 \mathrm{~cm}$ sebesar 23,3 $\%, 27,9 \%$ dan tertinggi sebesar 41,6\%. Data hasil run model dengan pengukuran lapangan terlihat mendapatkan trend yang sama dengan nilai terendah terjadi pada bulan Agustus dan September. Ini berhubungan dengan curah hujan yang terjadi di wilayah Kabupaten Gorontalo Provinsi Gorontalo rata-rata terendah pada Bulan Agustus dan September. Asdak (2002) mengatakan bahwa dari seluruh air hujan di daerah tropis, sekitar $75 \%$ dari air hujan tersebut masuk ke dalam tanah dalam bentuk kelembaban tanah (kapasitas lapang) pada tanah tidak jenuh dan sebagai air tanah pada tanah jenuh atau tanah berbatu.

\section{E. Pertumbuhan dan Produksi Tanaman}

\section{Indeks Luas Daun (ILD)}

Hasil pengamatan menunjukkan bahwa Indeks Luas Daun (ILD) meningkat sampai maksimum pada minggu ke 10 sebesar 8,29 dan kemudian menurun sampai minggu ke 12 
Beberapa hari setelah muncul bunga jantan peningkatan ILD secara cepat, perlahan menurun pada akhir fase tasseling (minggu ke 8) yang merupakan akhir dari pertumbuhan vegetatif dan mencapai puncak pada minggu ke 10 .

Gambar 4. Grafik Indeks luas Daun (ILD)

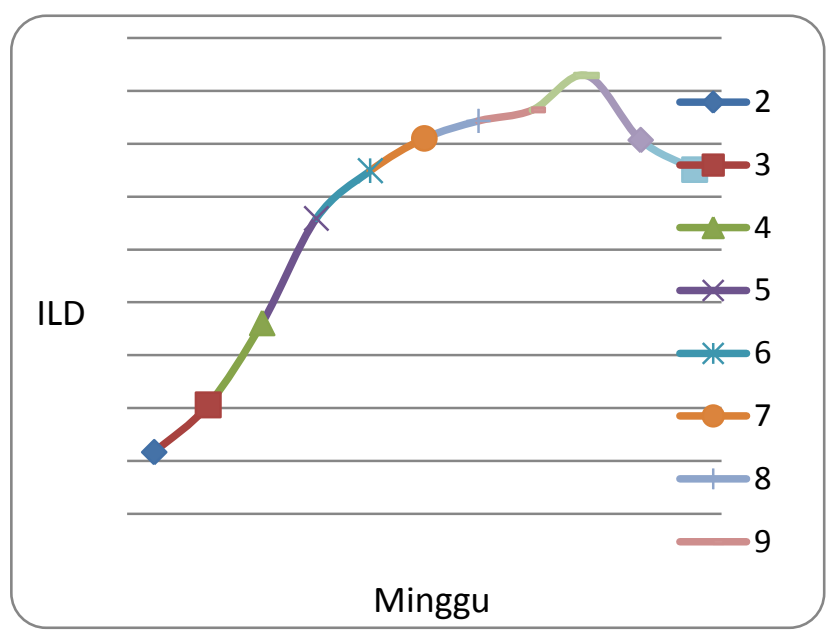

2. Produksi

Hasil penelian lapangan terhadap pertumbuhan dan hasil produksi adalah sebagai berikut : Rataan panjang tongkol tanaman jagung adalah $20,1 \mathrm{~cm}$, panjang tongkol merupakan salah satu komponen hasil yang turut berperan menentukan produksi jagung pipilan kering. Rataan tinggi tanaman adalah $211,2 \mathrm{~cm}$. Menurut Hosang et al. (2006) dalam Agus (2007), tinggi tanaman berkaitan erat dengan kerebahan batang, semakin tinggi suatu individu makin besar peluang individu tanaman tersebut mengalami kerebahan. Hal ini berpengaruh terhadap produktivitas tanaman. Rata-rata pipilan kering adalah $9,1 \mathrm{Kg}$ dengan potensi hasil biji jagung adalah 7,34 ton/ha. Bahar et al.1992 dalam Amir 2013 menjelaskan bahwa karakter agronomis dan komponen hasil memberikan kontribusi yang besar terhadap kemampuan menghasilkan biji (produktivitas) suatu varietas tanaman jagung.

Tingginya potensi produksi karena kondisi iklim di Kabupaten Gorontalo relatif mendukung pertumbuhan dan perkembangan jagung terutama curah hujan. Diantara faktor lingkungan yang banyak mempengaruhi produktivitas Jagung adalah ketersediaan air. Curah hujan dominan pengaruhnya terhadap produksi pipilan kering terutama pada ekosistem lahan kering (Moentono, 1993 dalam Amir 2013).

\section{KESIMPULAN DAN SARAN}

\section{Kesimpulan}

Hasil run model menunjukkan bahwa kabupaten Gorontalo memiliki periode surplus air yang panjang yakni terjadi pada bulan Januari sampai Juli dan pada bulan Oktober sampai Desember dimana Curah hujan melebihi Evapotranspirasi Potensial sedangkan periode defisit air terjadi pada bulan Agustus dan bulan September dimana Curah hujan lebih kecil dari Evapotranspirasi Potensial. Curah hujan bulanan berkisar antara $69,8 \mathrm{~mm}$ (September) sampai dengan 205,4 mm (Mei). Berdasarkan keadaan tersebut tipe zona agroklimat di kabupaten Gorontalo menurut Oldeman adalah tipe iklim B yang menunjukkan bahwa wilayah tersebut memiliki 7- 9 bulan basah berturut-turut dan 2 bulan kering.

\section{Saran}

Perlu dilakukan penelian lanjutan dengan cakupan wilayah yang lebih luas serta didukung oleh ketersediaan data iklim yang panjang untuk pengembangan tanaman Jagung di Provinsi Gorontalo.

\section{DAFTAR PUSTAKA}

Asdak, Chay. 2002. Hidrologi dan Pengelolaan

DAS. Yogyakarta: Gajah Mada

University Press

Aqil, M., I.U. Firmansyah, dan M. Akil. 2007.

Pengelolaan Air Tanaman Jagung.

Jagung Teknik Produksi dan

Pengembangan. Pusat Penelitian dan

Pengembangan Tanaman Pangan,

Departemen Pertanian. Jakarta. Hal 219230

Badan Pusat Statistik Propinsi Gorontalo. 2009.

Gorontalo dalam Angka 2009.

Badan Pusat Statistik Propinsi Gorontalo. http//Gorontalo bps.go.id/tiles/publikasi. Diakses pada tanggal 5 Desember 2014 
Buckman, O, Hanry, Brady, C, Nyle. 1982. Ilmu

Tanah. Jakarta: Barat Karya

Aksara

Dinas Pertanian dan Ketahanan Pangan Provinsi

Gorontalo. 2011. Gorontalo The

Agropolitan. Dinas Pertanian dan

Ketahanan Pangan Propinsi Gorontalo

Djufry Fadjry. 2012. Pemodelan neraca Air

tanah Untuk Pendugaan Surplus

dan Defisit Air untuk Pengembangan

Tanaman Pangan di Kabupaten

Merauke,Papua. Balai Pengkajian

Teknologi Pertanian Sulawesi Selatan

Handoko, 1993. Model Simulasi Pertanian:

Sebuah Alat Bantu Pengambilan

Keputusan (Simulation Modelling In

Agriculture : A Decision Support),

Agrotek 1 (2) : 36 -42.

Handoko, 1996. Analisis Sistem dan Model

Simulasi Komputer untuk Perencanaan

Pertanian di Indonesia. Jurusan

Geofisika dan Meteorologi. FMIPA. IPB.

Bogor

Hardjowigeno. 1993. Klasifikasi Tanah dan

Pedogenesis. Akademika

Pressindo. Jakarta

Islami, Titik dan W.H. Utomo. 1995. Hubungan

Tanah, Air dan Tanaman. IKIP

Semarang Press. Semarang.

Kartasapoetra A. G. 2004. Klimatologi :

Pengaruh Iklim Terhadap Tanah dan

Tanaman. PT Bumi Aksara. Jakarta

Purwono dan Hartono.2005. Bertanam

Jagung Unggul. Penebar

Swadaya,Jakarta.

Rogi, J. E. 1996. Penyusunan Model Simulasi

Dinamika Nitrogen Pertanaman Kelapa

Sawit (Elaeis guineensis Jacq) di Unit

Usaha Bekrie Provinsi Lampung.

Disertasi Doktoral. IPB. Bogor 